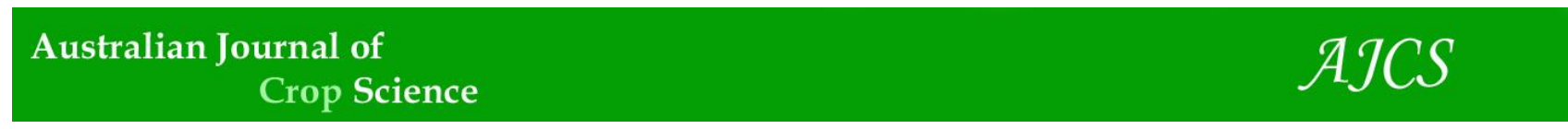

AJCS 12(06):967-974 (2018)

ISSN:1835-2707

doi: 10.21475/ajcs.18.12.06.PNE1063

\title{
Maize productivity cultivated as first crop in succession to different cover crops
}

\author{
Jefferson Luis Anselmo ${ }^{1}$, João William Bossolani ${ }^{2 *}$, Edson Lazarini ${ }^{2}$, Aguinaldo Jose Freitas Leal ${ }^{3}$, Rita de \\ Cássia Félix Alvarez ${ }^{3}$, Marcelo Valentini Arf ${ }^{1}$
}

\author{
${ }^{1}$ Fundação de Apoio à Pesquisa Agropecuária de Chapadao do Sul, Chapadao do Sul, MS 79560-000, Brazil \\ ${ }^{2}$ Universidade Estadual Paulista, Ilha Solteira, SP 15385-000, Brazil \\ ${ }^{3}$ Universidade Federal do Mato Grosso Do Sul, Chapadao do Sul, MS 79560-000, Brazil
}

\section{*Corresponding author: bossolani.agro@gmail.com}

\begin{abstract}
The plant residues left on the soil surface in no-tillage systems are an important source of nutrients for the subsequent crops, particularly under tropical climate. The aim of this study was to evaluate the cover plants grown during the off-season on development and productivity of maize cultivated in the first crop in no-tillage system. The experiment was conducted in the 2010/11 and 2011/12 agricultural years, in the experimental area. The experimental delineation used was the random blocks with four repetitions and eight treatments (as cover crops) consisted as follows: maize (alone), maize + Urochloa ruziziensis, sorghum, Crotalaria spectabilis, Urochloa ruziziensis, forage turnip, millet and fallow. The cover plants were placed in "Litter Bags", which were fixed to the ground in each plot and collected at 0, 15, 45, 75 and 115 days after the handling of the covers. Plant height, first ear insertion height and grain productivity were assessed in the culture of maize. Maize in single cropping or intercropping with Urochloa ruziziensis were good option to cover plants for the no-tillage system, due to maintenance of straw on the soil surface. Maize seeded on crop residues of $C$. spectabilis and $U$. ruziziensis showed more plant height; crop residues of forage and $U$. ruziziensis provided an increase maize culture productivity grown in succession.
\end{abstract}

Keywords: Cerrado, direct seeding, Zea mays.

Abbreviations: DSS_Direct Seeding System, C_carbon, N_nitrogen, C. spectabilis_Crotalaria spectabilis, U. ruziziensis_Urochloa ruziziensis, Z. mays_Zea mays, P. glaucum_Pennisetum glaucum, Embrapa_Brazilian Agricultural Research Corporation; SiBCS_ Brazilian Soil Classification System, O.M._Organic Matter, Ca_calcium, Mg_magnesium, K_potassium, P_phosphorus, S_sulfur, B_boron, Cu_copper, Fe_iron, Mn_manganese, Zn_zinc, V\%_base saturation, DAS_days after sowing, b.u._humid base, a.i._active ingredient, ANOVA_analysis of variance.

\section{Introduction}

The maize world's demand grows up for both human consumption and animal continue every year. Currently, there are limited options to produce energy from biomass; therefore, the search for increase productivity of this cereal looks necessary (Vogel et al., 2016). In Brazil, the average productivity of maize is too low. To use maize's most productive potential the management practices need to be improved to circumvent this problem. It is also necessary to mitigate the stresses caused by climatic conditions, especially the irregular rainfall.

In this sense, the Direct Seeding System (DSS) has stood since the phytomass production is essential for covering and protecting the soil from erosion, contributing to the soil fertility by proper nutrients cycling and improving water retention in soil and water use efficiency by the crop of maize, compared with the conventional system (Silva et al., 2015).

Pittelkow et al. (2015) reviewed the literature of 678 studies in 63 countries and suggested that the DSS may result a decline in crop production in the tropical regions, where maize is cultivated, compared to the conventional system. They suggested that the increase in production may occur even in regions where water is the limiting factor. The authors even suggested that adjustments in the system are necessary to optimize the no-tillage.

Among the management practices for the DSS, the choice of the cover crop is noteworthy, because one of the difficulties has been the maintenance of ground cover due to the high rate of decomposition of plant residues. On this aspect, Veronese et al. (2012) indicated that grasses as well as millet and species of Urochloa genus show high dry biomass production and more grow durability on the ground. In turn, legumes have the ability to associate with atmospheric nitrogen fixing bacteria due to their rapid rate of decomposition and mineralization, providing considerable amount of nitrogen for subsequent culture (Ferreira et al., 2011). Another culture that can provide nitrogen is the forage turnip, because of its root system that reaches deeper layers of soil.

However, different kinds of cover crops show variable accumulation of nutrients and mineralization time (Costa et al., 2015), which may influence the subsequent culture 
productivity (Torres et al., 2015). In this context, there is a chance that the different rates of decomposition of cover crops, as well as the differences in the accumulation of nutrients can change the production of maize. Therefore, researches on the subject are necessary, because they can indicate cover crops with mineralization similar to nutrients demand by maize, and it may reflect increase in productivity. Based on the above considerations, the objective of this experiment was to study the development and productivity of maize crop in succession to different cover crops.

\section{Results and discussion}

\section{Dry matter of cover crops and remaining dry matter}

The averages and the $\mathrm{F}$ values for dry matter of plants in function of cover crop and sampling times for 2010 and 2011 agricultural years are given in Table 1 . It was verified that there was significant interaction between the studied factors (cover crops $x$ sampling times) for the dry matter parameter in both experimental years. The unfolding of significant interaction for the agricultural year of 2010 is shown in Table 2.

In general, in all sampling times, it appears that straw produced by the maize in single cropping and in intercropping with Urochloa ruziziensis were higher than the other cover plants. This was observed in all collections held at the time when the cover plants were desiccated remaining the same behavior at 15,45 and 75 days after the cover plants management. In Sampling of 115 days, the remaining millet straw was similar to the maize, in both single and in intercropping. According to Foloni et al. (2016), this fact can be explained by high $\mathrm{C} / \mathrm{N}$ ratio found in the stalk of millet, which allow a relatively long period of soil cover in compared to other cover plants, such as $C$. spectabilis. This leguminous plant, with low $\mathrm{C} / \mathrm{N}$ ratio, provides a quick decomposition and nutrient cycling to the soil, mainly in regions with tropical climate (Cavallari et al., 2017).

In both cases, as they are species of Cycle 4 (C4), they excel in the photosynthetic efficiency and water use, converting these factors on biomass gain (Chioderoli et al., 2012). This fact becomes even more important when there is coexistence of more than one species in the same area (intercropping), where the efficient use of water becomes of utmost importance (Ferreira et al., 2014). These aspects, coupled with high capacity of phytomass production by maize culture, enable straw produced for the system to be larger than other cultures.

Among the plant species, $C$. spectabilis showed smaller phytomass production potential under the study condition. This can be explained because $C$. spectabilis is an erect and small size culture (Tivelli et al., 2013), besides the fact of having a C3 metabolism that presents a slower vegetative growth, as well as a shorter assimilation of atmospheric $C$ (Dantas et al., 2015).

The dynamics of the straw decomposition for the unfolding of the sampling times in each cover crop is shown in Fig 2. Fig 2 shows that the values for the cover plant phytomass were gradually reducing. For example, from 45 days after management, this decomposition occurred more steeply. In samples conducted at 75 days, there was a decrease of more than $50 \%$ vegetative material on the soil surface. It can also be observed that in the sampling performed at 115 days, the remaining mass of $C$. spectabilis presented approximately $65 \%$ reduction compared to the initial mass. Thus, it is confirmed that the decomposition of plant residues is directly associated with the $\mathrm{C} / \mathrm{N}$ ratio of the material and non-grass species (mainly leguminous), providing less protection time to the soil, since they have a higher decomposition rate and lower remaining time than the nutrient grasses (Costa et al., 2014).

In general, the maize in single and in intercropping, and also millet at the end of 115 days, presented similar remaining mass, being responsible for keeping the largest amount of straw on the soil. Thus, the permanence of this straw on the soil surface becomes important for the maintenance and protection of the soil-plant system, promoting benefits for the maintenance of humidity, reduction of thermal amplitudes and favoring soil biota and nutrient cycling (Costa et al., 2014).

The retention of the residues for forage turnip, sorghum and $U$. ruziziensis was similar until 115 days after their management, which retained $48 \%, 38 \%$ and $40 \%$ of the initial straw, respectively. These cover crops together with $C$. spectabilis were those that presented lower values of vegetative phytomass at the end of the studied period.

Table 3. shows the interaction between cover crops $x$ sampling times for dry matter values in 2011 agricultural year.

For this experimental year (2011), for the sampling times within each cover crop, maize in intercropping with Urochloa ruziziensis showed the highest dry matter production when compared to other cover plants in four out of five sampling seasons. In the last sampling, the maize in single crop was similar to the maize in intercropping. It is also evident that regardless of sampling time, the average values of all cover crops are lower than previous year, due to the prolonged drought during the conduct of cover plants, which was responsible for reducing the potential of plant.

Even in drought conditions, the intercropping system had a higher contribution to the phytomass of cover crops, a similar fact that was occurred in the previous year. In a cultivation system that presents the coexistence of two plant species under influence of adverse weather conditions, the efficient use of water is of the utmost importance for the establishment, development and permanence of the cultures in the area, since it correlates the amount of dry matter produced with the quantity of water consumed (Chioderoli et al., 2012). As the intercropping system used two species of C4 metabolism, the above premise is attended, ensuring a greater productive potential compared with other cover crops.

As occurred in 2010, C. spectabilis had the lowest plant biomass production, since this species have a C3 metabolism, more sensitive to adverse weather conditions (Dantas et al., 2015). The millet and sorghum presented values below $1 \mathrm{t} \mathrm{ha}^{-1}$, showing a lower productive behavior than other grasses and even the brassica (forage turnip) used.

The cover crop management systems vary according to their purposes. If the objective is provide the soil cover, plants with higher $\mathrm{C} / \mathrm{N}$ ratio must be chosen and must be on the surface of the soil, having slower decomposition. If the aim is to supply the nutrients in short time for the successor culture, plants that present lowest $\mathrm{C} / \mathrm{N}$ ratio must be chosen (Costa et al., 2014). 
Table 1. Dry matter of plants in function of cover crops and sampling times, Chapadão do Sul, MS, Brazil.

\begin{tabular}{|c|c|c|c|}
\hline \multirow{2}{*}{\multicolumn{2}{|c|}{ Cover crops (C.C.) }} & \multicolumn{2}{|c|}{ Dry matter of plants $\left(\mathrm{kg} \mathrm{ha}^{-1}\right)$} \\
\hline & & 2010 & 2011 \\
\hline \multicolumn{2}{|c|}{ Zea mays } & 5012 & 1102 \\
\hline \multicolumn{2}{|c|}{ Zea mays + Urochloa ruziziensis } & 4865 & 1358 \\
\hline \multicolumn{2}{|c|}{ Raphanus sativus } & 3178 & 840 \\
\hline \multicolumn{2}{|c|}{ Crotalaria spectabilis } & 1751 & 367 \\
\hline \multicolumn{2}{|c|}{ Pennisetum glaucum } & 3621 & 632 \\
\hline \multicolumn{2}{|c|}{ Sorghum bicolor } & 3930 & 580 \\
\hline \multicolumn{2}{|c|}{ Urochloa ruziziensis } & 2972 & 775 \\
\hline \multicolumn{4}{|c|}{ Sampling times (S.T.) } \\
\hline \multicolumn{2}{|l|}{$\overline{0}$} & 5132 & 1109 \\
\hline \multicolumn{2}{|l|}{15} & 4668 & 1005 \\
\hline \multicolumn{2}{|l|}{45} & 3675 & 813 \\
\hline \multicolumn{2}{|l|}{75} & 2491 & 633 \\
\hline \multicolumn{2}{|l|}{115} & 2127 & 479 \\
\hline \multirow{3}{*}{$\mathrm{F}$} & C.C. & $205.57^{* *}$ & $1147.25 * *$ \\
\hline & S.T. & $386.86^{* *}$ & $964.84 * *$ \\
\hline & C.C $\times$ S.T. & $7.67^{* *}$ & $27.33^{* *}$ \\
\hline \multirow{2}{*}{\multicolumn{2}{|c|}{$\begin{array}{l}\text { DMS } \\
\text { C.V. (\%) }\end{array}$}} & 335.96 & 41.94 \\
\hline & & 9.76 & 5.46 \\
\hline
\end{tabular}

ns, * and ${ }^{* *}$ is, respectively, not significant, significant at $(\mathrm{P} \leq 0.05)$ and $(\mathrm{P} \leq 0.01)$ probability by $\mathrm{F}$ test. Averages followed by the same letters in the column do not differ by Tukey's test at the $5 \%$ significance level.

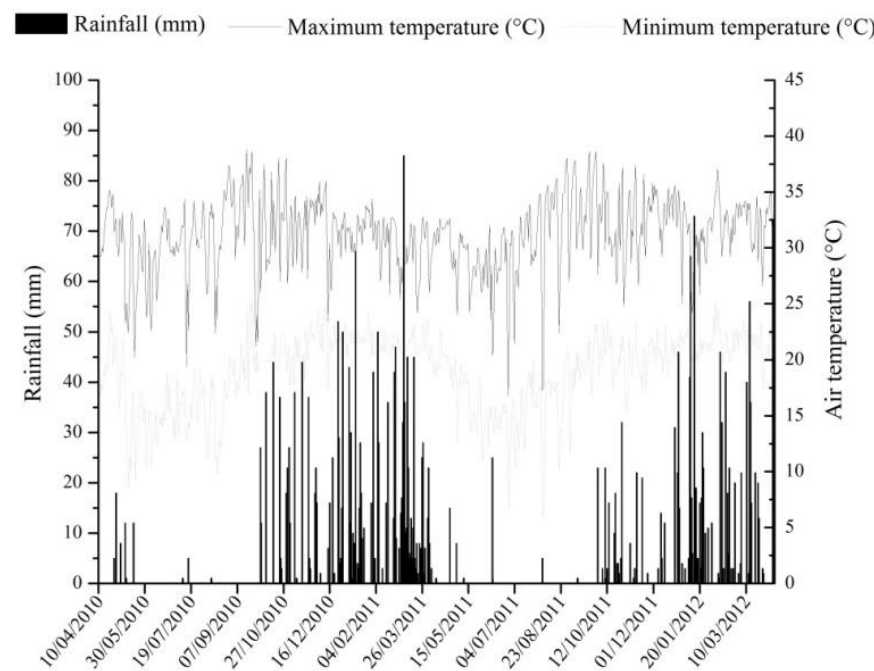

Fig 1. Climatic data of rainfall, maximum and minimum temperature recorded during the conduction of experiment. Chapadão do Sul, MS, Brazil.

Table 2. The interaction between cover crops and sampling times, Chapadão do Sul, MS, Brazil, 2010.

\begin{tabular}{|c|c|c|c|c|c|}
\hline \multirow{3}{*}{ Cover crops (C.C.) } & \multicolumn{5}{|c|}{ Sampling times } \\
\hline & 0 & 15 & 45 & 75 & 115 \\
\hline & \multicolumn{5}{|c|}{------------------------ kg ha ${ }^{-1}$----------------------- } \\
\hline Zea mays & $6528 a b$ & $6374 \mathrm{a}$ & $5570 \mathrm{a}$ & 3596 a & $2991 \mathrm{a}$ \\
\hline Zea mays + Urochloa ruziziensis & 7012 a & $6385 a$ & 5289 a & $3200 a b$ & $2450 a b$ \\
\hline Raphanus sativus & $4471 \mathrm{c}$ & $4058 \mathrm{~cd}$ & $2975 \mathrm{~cd}$ & $2277 \mathrm{~cd}$ & 2108 b \\
\hline Crotalaria spectabilis & $2509 d$ & $2091 \mathrm{e}$ & $1862 \mathrm{c}$ & 1407 e & $887 \mathrm{c}$ \\
\hline Pennisetum glaucum & 5027 c & $4759 \mathrm{bc}$ & 3451 bc & $2386 \mathrm{~cd}$ & 2481 \\
\hline Sorghum bicolor & $5851 b$ & 5013 b & 3886 b & 2725 bc & $2178 \mathrm{~b}$ \\
\hline Urochloa ruziziensis & $4529 \mathrm{c}$ & $4004 \mathrm{~d}$ & $2688 d$ & 1844 de & 1795 b \\
\hline $\mathrm{F}$ & 73.19** & $71.66 * *$ & $59.04 * *$ & $18.33^{* *}$ & $14.03 * *$ \\
\hline DMS & \multicolumn{5}{|c|}{751.24} \\
\hline
\end{tabular}
by Tukey's test at the $5 \%$ significance level. 


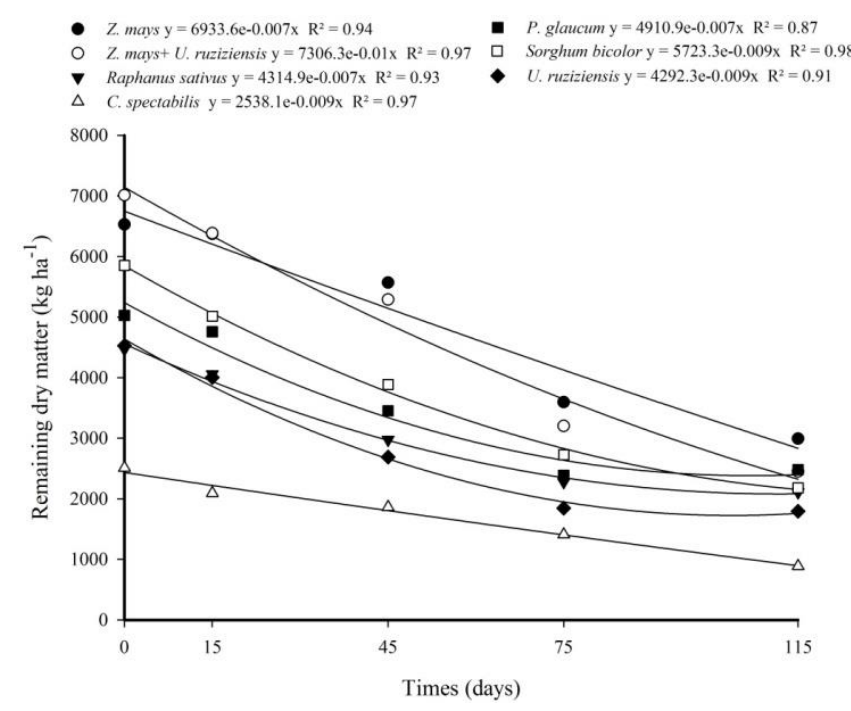

Fig 2. Remaining dry matter of plants after deposition of the bags on the soil surface, Chapadão do Sul, MS, Brazil, 2010.

Table 3. The interaction between cover crops and sampling times. Chapadão do Sul, MS, Brazil, 2011.

\begin{tabular}{|c|c|c|c|c|c|}
\hline \multirow{3}{*}{ Cover crops (C.C.) } & \multicolumn{5}{|c|}{ Sampling times } \\
\hline & 0 & 15 & 45 & 75 & 115 \\
\hline & \multicolumn{5}{|c|}{ - } \\
\hline Zea mays & $1447 \mathrm{~b}$ & $1290 \mathrm{~b}$ & $1087 \mathrm{~b}$ & $939 \mathrm{~b}$ & $747 \mathrm{a}$ \\
\hline Zea mays + Urochloa ruziziensis & 1883 a & 1708 a & 1332 a & 1037 a & $832 a$ \\
\hline Raphanus sativus & $1111 d$ & $1048 \mathrm{c}$ & $917 c$ & $663 c$ & $462 \mathrm{~b}$ \\
\hline Crotalaria spectabilis & $555 \mathrm{~g}$ & $471 \mathrm{e}$ & $373 f$ & 279 e & $158 \mathrm{c}$ \\
\hline Pennisetum glaucum & 809 e & $760 d$ & $655 \mathrm{de}$ & $534 d$ & $403 \mathrm{~b}$ \\
\hline Sorghum bicolor & $749 \mathrm{f}$ & $690 \mathrm{~d}$ & 594 e & $485 d$ & $381 \mathrm{~b}$ \\
\hline Urochloa ruziziensis & 1207 c & $1065 \mathrm{c}$ & $737 d$ & $493 d$ & $373 b$ \\
\hline $\mathrm{F}$ & $428.46^{* *}$ & $351.65 * *$ & $215.48^{* *}$ & $148.85^{* *}$ & $112.14^{* *}$ \\
\hline
\end{tabular}

$\mathrm{ns},{ }^{*}$ and ${ }^{* *}$ is, respectively, not significant, significant at $(\mathrm{P} \leq 0.05)$ and $(\mathrm{P} \leq 0.01)$ probability by $\mathrm{F}$ test. Averages followed by the same letters in the column do not differ by Tukey's test at the $5 \%$ significance level.

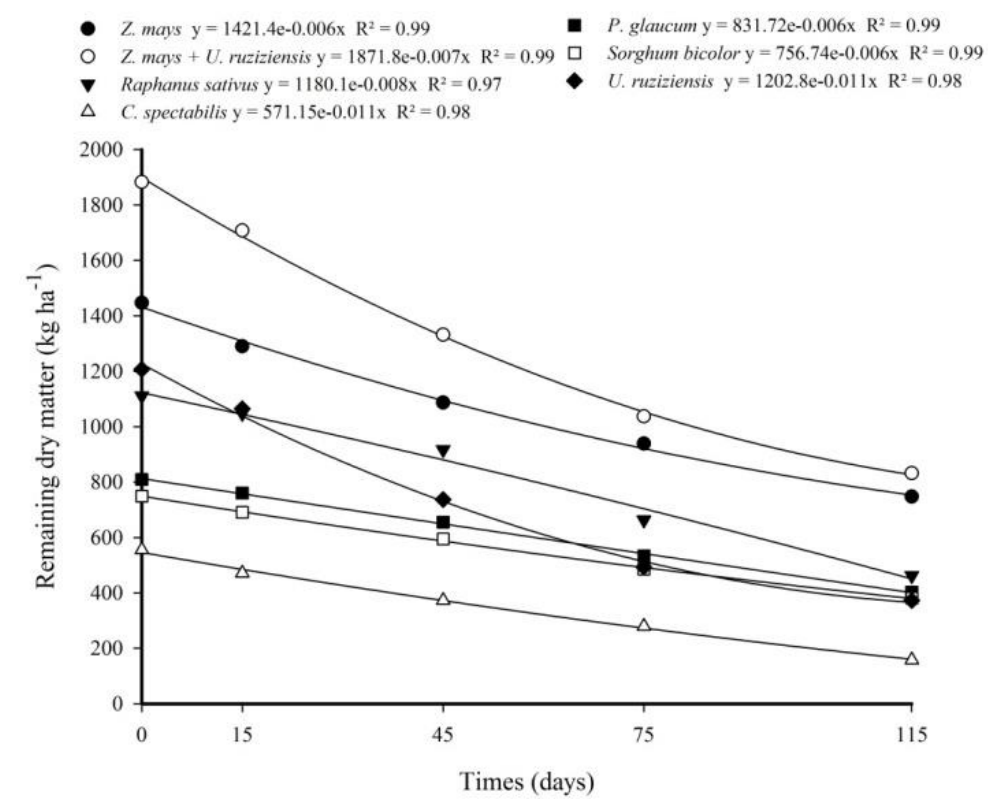

Fig 3. Remaining dry matter of plants after the deposition of the bags of decomposition on the soil surface, Chapadão do Sul, MS, Brazil, 2011/12 
Table 4. Plant height, ear insertion height and grain yield of maize in function of cover crops. Chapadão do Sul, MS, Brazil, 2011/12.

\begin{tabular}{lccc}
\hline \multirow{2}{*}{ Cover crops (C.C.) } & Plant height & Ear insertion height & Grain yield \\
\cline { 2 - 4 } & $(\mathrm{m})$ & $(\mathrm{m})$ & $\left(\mathrm{kg} \mathrm{ha}^{-1}\right)$ \\
\hline Zea mays & $2.34 \mathrm{ab}$ & $1.26 \mathrm{a}$ & $11077 \mathrm{ab}$ \\
Zea mays + Urochloa & $2.36 \mathrm{ab}$ & $1.26 \mathrm{a}$ & $11029 \mathrm{ab}$ \\
ruziziensis & $2.45 \mathrm{ab}$ & $1.29 \mathrm{a}$ & $14604 \mathrm{a}$ \\
Raphanus sativus & $2.50 \mathrm{a}$ & $1.30 \mathrm{a}$ & $12770 \mathrm{~b}$ \\
Crotalaria spectabilis & $2.46 \mathrm{ab}$ & $1.42 \mathrm{a}$ & $13682 \mathrm{ab}$ \\
Pennisetum glaucum & $2.17 \mathrm{~b}$ & $1.38 \mathrm{a}$ & $10163 \mathrm{~b}$ \\
Sorghum bicolor & $2.52 \mathrm{a}$ & $1.35 \mathrm{a}$ & $14426 \mathrm{a}$ \\
Urochloa ruziziensis & $2.43 \mathrm{ab}$ & $1.31 \mathrm{a}$ & $10890 \mathrm{ab}$ \\
Fallow & $3.22^{* *}$ & $0.62 \mathrm{~ns}$ & $4.99^{* *}$ \\
\hline F & 0.29 & 0.36 & 3733 \\
\hline DMS & 5.19 & 11.43 & 12.76 \\
\hline C.V. $(\%)$ & 5.05
\end{tabular}

$\mathrm{ns}, *$ and ${ }^{* *}$ is, respectively, not significant, significant at $(\mathrm{P} \leq 0.05)$ and $(\mathrm{P} \leq 0.01)$ probability by F-test. Averages followed by the same letters in the column do not differ by Tukey's test at the $5 \%$ significance level.

The results of cover crops within each sampling period in 2011 (Figure 3) show that there is a gradual decrease in the values of dry matter remaining in the area, due to its decomposition.

The dynamic of straw decomposition as a function of time, was presented in Figure 3, showing that in relative terms, decomposition speed was lower when compared to the previous year. For example in 2010 agricultural year, more than $50 \%$ of the initial plant material had already been decomposed at 75 days after the cover plants management. The plants tended to change the growth rate and the translocation pattern of dry matter under water stress conditions, reducing growth and increasing their thickness (high in lignin concentration, due to less dilution effect), leaf area and other anatomical and morphological characteristics, as well as, the transpiration rate, stomatal conductance and photosynthetic rate (Steinberg et al., 1990). These facts explain the smallest dry matter accumulation and the slowest decomposition speed of the material on the soil.

At the first year, $C$. spectabilis presented higher decomposition rate compared to other cover plants, coming to end of 115 days after its management, with only $28 \%$ of the initial material remained. The high deterioration rate of this species is associated with the close $\mathrm{C} / \mathrm{N}$ ratio present in their tissue (Cavallari et al., 2017).

According to Costa et al. (2014), the permanence of greater volume for grass straw is subject to the decomposition rate of the material in the field due to their higher $\mathrm{C} / \mathrm{N}$ ratio and larger lignin concentration at the flowering time, which can result in slow mineralization or nutrient availability of the straw, with possibilities to produce beneficial effects in the long term.

According to Silva et al. (2015), the non-tillage system challenge in the Cerrado region lies in the fact to get the ground cover establishment in March or April with sufficient quantity and rusticity. The Cerrado have a dominant dry weather condition in the winter with short photoperiod, and also high rate of decomposition of the mulch in the summer, providing constant supply of material to the soil until the beginning of the next crop planting.

Aita and Giancomini (2003) proposed a management strategy that consists of mixture of leguminous and grasses; in addition to protecting the soil and addition of $\mathrm{N}$, intercropping system provides dry matter production with intermediate $\mathrm{C} / \mathrm{N}$ ratio, obtaining less decomposition rate of crop residues, and synchronization between $\mathrm{N}$ supply and demand by economical crops.

\section{Plant height, ear insertion height and grain yield of maize}

The results of plant height, ear height and grain yield in maize culture in function of different cover plants are presented in Table 4. To evaluate the height of plants, it is observed that maize, when grown on $C$. spectabilis and $U$. ruziziensis, showed higher plant height when compared to the other treatments. According to Boddey et al. (2010) leguminous that contributes to the nitrogen input by biological fixation certainly plays important role in promoting carbon accumulation in soil under no-tillage system, which may be due to the slow release of nitrogen waste on the surface, favoring maize root growth. This effect can influence even the height of plants, a fact that may explain the higher maize height, when it was grown on $C$. spectabilis residues.

The smaller plant height was observed when maize was grown on sorghum residues. Muraishi et al. (2005) observed that maize plants obtained smaller plant height values when grown in the sorghum straw, corroborating the results of the study. According to Embrapa (2003) it is not recommended to use sorghum as preceding crop of maize in crop rotation system.

For ear height, there were no statistically significant differences between treatments. With regard to grain yield we verified that when the maize was sown on forage turnip and Urochloa ruziziensis, it had higher grain yield, differing from results obtained by Carvalho et al. (2004), where crotalaria grown in spring increased $18.5 \%$ in maize yield in succession, compared to the fallow in both non-tillage and conventional tillage systems.

Forage turnip, although did achieve the biological nitrogen fixation such as $C$. spectabilis, but showed effective potential in increasing the $\mathrm{N}$ availability in the soil, since forage turnip removes even deeper layers in the soil. In addition, forage turnip is a natural soil decompressor, promoting greater aeration and consequently, higher root growth. These beneficial factors may have influenced directly the increase 
of the culture productivity, compared to the other covers (Silva et al., 2007).

Several studies have reported the positive effect of cover crops on maize productivity (Carvalho et al., 2007; Sousa Neto et al., 2008), and many others have mentioned the contribution of the remaining crop residues nitrogen. The beneficial effects of the use of cover crops are diverse, including the better use of nitrogen fertilizer and the remaining nitrogen supply from the aerial part of the cover crops. According to Silva et al. (2005), utilization of nitrogen from plant residues by maize was in the following order: crotalaria> millet> dry mass of maize, but most of the nitrogen from plant residues was not absorbed by the maize. Regarding the minor productivities, they occurred on succession in the same family covers. This aspect has given little consideration by the producers, since there is a higher probability of incidence of common diseases to both species in successive crops, especially in situations of stress to the plant, such as low levels of $\mathrm{N}$ and other essential elements Silva et al. (2005). The occurrence of leaf phytopathogens associated with the nutritional deficiencies can promote a leaf area culture reduction (premature senescence), reducing the photosynthetic activity and consequently, its productive potential (Silva et al., 2007).

\section{Materials and methods}

\section{Plant materials and description of the study area}

The survey was conducted in the experimental area of the Fundação de Apoio à Pesquisa Agropecuária de Chapadão, located in the municipality of Chapadão do Sul, Mato Grosso do Sul, situated $18^{\circ} 41^{\prime}$ South latitude and $52^{\circ} 40^{\prime}$ 'West longitude of Greenwich, with an altitude of $810 \mathrm{~m}$. The experiment was conducted during the agricultural years of 2010/11 and 2011/12 in no-tillage system in growing area of approximately 13 years old and previously cultivated with soybean culture.

The climate in this region is the type Aw, according to classification of Kopen, tropical wet and dry climate, with rainy season in summer and dry in the winter and annual average precipitation of $1,800 \mathrm{~mm}$. The daily values of pluvial precipitation and minimum and maximum air temperature recorded during the conduction of experiment is presented in Fig 1.

The soil of experimental area is classified as Dystrophic Red Latosol and clayey texture, according to Brazilian System of Soil Classification - SiBCS (Embrapa, 2013), whose chemical characteristics of layer of 0.0 to $0.20 \mathrm{~m}$ revealed the values: O.M: $28 \mathrm{~g} \mathrm{dm}^{-3} ; \mathrm{pH}\left(\mathrm{CaCl}_{2}\right)$ : 5.2; $\mathrm{Ca}, \mathrm{Mg}$ and $\mathrm{K}$ : 38.9 and $1.7 \mathrm{mmol}_{\mathrm{c}} \mathrm{dm}^{-3}$ respectively; $\mathrm{P}$ (resin), S, B, Cu, Fe, $\mathrm{Mn}$ and $\mathrm{Zn}: 33 ; 6 ; 0.21 ; 3.3 ; 67 ; 20.9$ and $9.8 \mathrm{mg} \mathrm{dm}^{-3}$ respectively and $V=68 \%$. The growing area was under notillage system for thirteen years.

\section{Treatments and experimental design}

Eight treatments have been established with four repetitions: three coverage crops sowed in the off-season and a fallow area, namely: 1- maize (Zea mays), 2 - maize + Urochloa ruziziensis, 3 - sorghum (Sorghum bicolor), 4 Crotalaria spectabilis, 5 - Urochloa ruziziensis, 6 - forage turnip (Raphanus sativus), 7 - millet (Pennisetum glaucum) and 8 - fallow. The experimental design used was in random blocks.

\section{Execution of the experiment}

The covers were mechanically sown in the days $4 / 9 / 2010$ and 4/9/2011. For maize and sorghum, the spacing was 0.45 $\mathrm{m}$ between lines, using the hybrids 2B587 HX and 1G282, respectively. In relation to Crotalaria spectabilis, forage turnip, Urochloa brizantha and millet, they were mechanically sown in $0.22 \mathrm{~m}$ spacing between lines. Regarding to intercroping maize + Urochloa ruziziensis, it was firstly held the sowing of Urochloa ruziziensis by broadcasting system, using $10 \mathrm{~kg} \mathrm{ha}^{-1}$ of seed, then maize was sown in the $0.45 \mathrm{~m}$ spacing between lines. The emergence of plants occurred at 7 days after sowing (DAS). In the period between September 2010 and March 2011, the area was occupied with the soy culture.

Before the sowing of summer maize (first harvest), the area received herbicide application $\left(1.560 \mathrm{~g} \mathrm{ha}^{-1}\right.$ of a.i. of glifosate $+403 \mathrm{~g} \mathrm{ha}^{-1}$ do a.i. of 2.4-D), with the aim of desiccating to implement the maize plots in no-tillage system.

\section{Evaluations}

Before the sowing of the maize crop (harvest 2011/12), the crop covers were handled with horizontal mechanical disintegrator, with approximately $15 \mathrm{~cm}$ of cutting height, in order to fragment and distribute the crop residues evenly in the cultivation area. After this procedure, random sampling were conducted with quadrant of $0.25 \mathrm{~m}(0.5 \times 0.5 \mathrm{~m})$ in eight points, representing each soil coverage. The material collected in the quadrant was put in "Litter Bags", as described by Santos and Whitford (1981) and placed in each plot fixed to the soil for subsequent collections over the periods $0,15,45,75$ and 115 days after the management of the covers. In each sampling, the material was subjected to drying in an oven dryer with renewal and forced air circulation at a temperature of $60 \pm 5^{\circ} \mathrm{C}$, until a constant weight. The productivity of the shoot dry mass was obtained by the arithmetic average between sampled points in each plot, with average values extrapolated to $\mathrm{kg} \mathrm{ha}^{-1}$.

The hybrid used in 2011/12 was the AG 7098 PRO2 inoculated mechanically on the day $11 / 21 / 2011$ in the 0.45 $\mathrm{m}$ spacing between lines and 3 seeds per meter, to obtain a final population of approximately 67,000 plants per hectare according to recommendations of Barbosa (2007). The emergence of plants occurred on 11/28/2011, 7 days after sowing (DAS).

The basic fertilization in the furrow sowing was constituted by $400 \mathrm{~kg} \mathrm{ha}^{-1}$ of the formula $(8 / 24 / 12)$, calculated in accordance with the chemical characteristics of the soil and taking into account the range of expected productivity (10$12 \mathrm{t} \mathrm{ha}^{-1}$ ) and the recommendations of Raij et al. (1997). The nitrogen side-dressing was split in two times conducted on $12 / 8 / 2011$ and $1 / 10 / 2012$, when the maize plants were fully expanded with 4 and 6 leaves, using $100 \mathrm{~kg} \mathrm{ha}^{-1}$ of nitrogen in both applications, having urea as source of nitrogen $(45 \%$ of nitrogen). The applications were done through a mechanized system, which distributed the fertilizer on the surface of the ground. 
On the occasion of the full flowering of the maize plants, five plants were measured per plot. All of the following characteristics such as plant height (measuring from soil level to "flag" leaf insert) and ear height (measurement from soil level to first ear insert) were measured.

The harvest was held on 4/10/2012, for approximately 130 days after emergence of the plants, and harvested the 2 central lines of $4 \mathrm{~m}$ in length of each plot.

The grain yield was obtained from the thrashing and weighing of grain coming from all the earn harvested in the floor area of the plot, which was converted to $\mathrm{kg} \mathrm{ha}^{-1}$ and corrected to $130 \mathrm{~g} \mathrm{~kg}^{-1}$ content water (b.u). The grain moisture content was obtained by indirect non-destructive electrical method using the handset Multi-grain (DickeyJohn $\left.{ }^{\circledast}\right)$, which provides direct reading.

\section{Statistical analysis}

The data were submitted to the F-test analysis of variance (ANOVA), with qualitative treatments compared by Tukey test $(P \leq 0.05)$ and polynomial regression analysis to the quantitative parameters.

\section{Conclusion}

Cover cropping with high potential for straw production and cycling of nutrients is a practice of utmost importance to increase the efficiency of the SSD system in regions of tropical climate. The maize on single cropping or on intercropping with Urochloa ruziziensis are viable options of predecessor crops, presenting high residual of straw on the soil surface and ensuring greater protection of the soil for longer time. With regard to the benefits for the maize crop sown in the spring/summer period, the crop residues of forage turnip and Urochloa ruziziensis provided an increase in grain yield.

\section{Acknowledgements}

Fundação de Apoio à Pesquisa Agropecuária de Chapadao do Sul that made possible the realization of this research.

\section{References}

Aita C, Giacomini SJ (2003) Decomposição e liberação de nitrogênio de resíduos culturais de plantas de cobertura de solo solteiras e consorciadas. Rev Bras Cienc Solo. 27:601-612.

Barbosa CA (2007) Manual da Cultura do Milho (Zea mays). Viçosa: AgroJuris 123p.

Boddey RM, Jantalia CP, Conceição PC, Zanatta JA, Bayer C, Mieln Iczuk J, Dieckow J, Santos HP, Denardin JE, Aita C, Giacomini SJ, Alves BJR, Segundo U (2010) Carbon accumulation at depth in Ferrasols under zero-till subtropical agriculture. Glob Change Biol. 16:784-795.

Carvalho IQ, Silva MJS, Pissaia A, Pauletti V, Possamai JC (2007) Espécies de cobertura de inverno e nitrogênio na cultura do milho em sistema de plantio direto. Sci Agrar. 8:179-184.

Carvalho MAC de, Soratto RP, Athaiyde MLF, Arf O, Sá ME (2004) Produtividade do milho em sucessão a adubos verdes no sistema de plantio direto e convencional. Pesq Agrop Bras. 30:47-53.

Cavallari LA, Soares CMJ, de Oliveira MS, Rambo JR (2017) Produção de Fitomassa e Cobertura do Solo de Crotalaria juncea. Cad Agroecol. 11:1-12.

Chioderoli CA, Mello LMM, Grigolli PJ, Furlani CEA, Silva JOR, Cesarin AL (2012) Atributos físicos do solo e produtividade de soja em sistema de consórcio milho e braquiária. Rev Bras Eng Agric Ambient. 16:37-43.

Costa NR, Andreotti M, Buzetti S, Lopes KSM, Santos FGD, Pariz CM (2014) Acúmulo de macronutrientes e decomposição da palhada de braquiárias em razão da adubação nitrogenada durante e após o consórcio com a cultura do milho. Rev Bras Cienc Solo. 38:1223-1233.

Costa NR, Andreotti M, Ulian NA, Costa BS, Pariz CM, Teixeira Filho MCM (2015) Acúmulo de nutrientes e tempo de decomposição da palhada de espécies forrageiras em função de épocas de semeadura. Biosci J. 31:818-829.

Dantas RA, Carmona R, de Carvalho AM, Rein TA, Malaquias JV, dos Santos JDDG (2015) Produção de matéria seca e controle de plantas daninhas por leguminosas consorciadas com cana de açúcar em cultivo orgânico. Pesq Agrop Bras. 50:681-689.

Embrapa (Empresa Brasileira de Pesquisa Agropecuária) (2003) O cultivo do milho verde. Brasília-DF. 204p.

Embrapa (Empresa Brasileira de Pesquisa Agropecuária) (2013) Sistema brasileiro de classificação de solos. Centro Nacional de Pesquisa de Solos - CNPS, BrasíliaDF. 306p.

Ferreira EA, Coletti AJ, Silva WMD, Macedo FGD, Albuquerque AND (2014) Desempenho e uso eficiente da terra de modalidades de consorciação com milho e forrageiras. Rev Caatinga. 27:22-29.

Ferreira EPDB, Stone LF, Partelli FL, Didonet AD (2011) Produtividade do feijoeiro comum influenciada por plantas de cobertura e sistemas de manejo do solo. Rev Bras Eng Agric Ambient. 15:695-701.

Foloni JSS, Catuchi TA, de Moraes Barbosa A, Calonego JC, Tiritan CS (2016) Acúmulo de nutrientes e relação $\mathrm{C} / \mathrm{N}$ em diferentes estádios fenológicos do milheto submetido à adubação nitrogenada. Rev Agroambiente. 10:1-9.

Muraishi CT, Leal AJF, Lazarini E, Rodrigues LR, Gomes Júnior FG (2005) Manejo de espécies vegetais de cobertura de solo e produtividade do milho e da soja em semeadura direta. Acta Sci Agron. 27:199-207.

Pittelkow CM, Liang X, Linquist BA, Van Groenigen KJ, Lee J, Lundy ME, Gestel N, Six J, Venterea RT, Van Kessel C (2015) Productivity limits and potentials of the principles of conservation agriculture. Nature. 517:365368.

Raij B Van, Cantarella H, Quaggio JA, Furlani AMC (1997) Recomendações de adubação e calagem para o Estado de São Paulo, 2nd ed. Instituto Agronômico/Fundação IAC, Campinas (IAC. Boletim Técnico, 100).

Santos PF, Whitford WG (1981) The efects of microarthropods on litter decompositionin a Chihuazhuan ecosystem. Ecology. 62:654-663. 
Silva AA, da Silva PRF, Suhre E, Argenta G, Strieder ML, Rambo L (2007) Sistemas de coberturas de solo no inverno e seus efeitos sobre o rendimento de grãos do milho em sucessão. Cienc Rural. 37:928-935.

Silva EC, Ferreira SM, Silva GP, Assis RL, Guimarães GL (2005) Épocas e formas de aplicação de nitrogênio no milho sob plantio direto em solo de Cerrado. Rev Bras Cienc Solo. 29:725-733.

Silva FA, Freitas FCL, Rocha PRR, Cunha JLL, Dombroski JLD, Coelho MEH, Lima MFP (2015) Milho para ensilagem cultivado nos sistemas de plantio direto $e$ convencional sob efeito de veranico. Semin Cienc Agrar. 36:327-340.

Sousa Neto EL, Andrioli I, Beutler NA, Centurion JF (2008) Atributos físicos do solo e produtividade de milho em resposta a culturas de pré-safra. Pesq Agrop Bras. 43:255-269.
Steinberg SL, Miller JC, McFarland MJ (1990) Dry matter partitioning and vegetative growth of young peach trees under water stress. Funct Plant Biol. 17:23-36.

Tivelli SW, Kano C, Purquerio LFV, Wutke EB, Ishimura I (2013) Desempenho do quiabeiro consorciado com adubos verdes eretos de porte baixo em dois sistemas de cultivo. Hortic Bras. 31:483-488.

Torres JLR, Pereira MG, Rodrigues Junior DJ, Loss A (2015) Production, decomposition of residues and yield of maize and soybeans grown on cover crops. Rev Cienc Agronom. 46:451-459.

Veronese M, Francisco EAB, Zancanaro L, Rosolem CA (2012) Plantas de cobertura e calagem na implantação do sistema plantio direto. Pesq Agrop Bras. 47:11581165.

Vogel E, Deumlich D, Kaupenjohann M (2016) Bioenergy maize and soil erosion - Risk assessment and erosion control concepts. Geoderma. 261:80-92. 